\title{
Surveillance Metrics of SARS-CoV-2 Transmission in Central Asia: Longitudinal Trend Analysis
}

Lori Ann Post ${ }^{1}$, PhD; Elana T Benishay ${ }^{2}$, BSc; Charles B Moss ${ }^{3}$, PhD; Robert Leo Murphy ${ }^{4}$, MD; Chad J Achenbach ${ }^{5}$, MD, MPH; Michael G Ison ${ }^{5}$, MD, MSc; Danielle Resnick ${ }^{6}$, PhD; Lauren Nadya Singh ${ }^{1}$, MPH; Janine White ${ }^{1}$, MA; Azraa S Chaudhury ${ }^{2}$, BA; Michael J Boctor ${ }^{2}$, BSc; Sarah B Welch ${ }^{1}$, MPH; James Francis Oehmke ${ }^{1}$ PhD

${ }_{1}^{1}$ Buehler Center for Health Policy and Economics, Feinberg School of Medicine, Northwestern University, Chicago, IL, United States

${ }^{2}$ Feinberg School of Medicine, Northwestern University, Chicago, IL, United States

${ }^{3}$ Institute of Food and Agricultural Sciences, University of Florida, Gainsville, FL, United States

${ }^{4}$ Institute for Global Health, Feinberg School of Medicine, Northwestern University, Chicago, IL, United States

${ }^{5}$ Divison of Infectious Disease, Feinberg School of Medicine, Northwestern University, Chicago, IL, United States

${ }^{6}$ International Food Policy Research Institute, Washington, DC, United States

\section{Corresponding Author:}

Lori Ann Post, PhD

Buehler Center for Health Policy and Economics

Feinberg School of Medicine

Northwestern University

420 E Superior

Chicago, IL, 60611

United States

Phone: 12039807107

Email: lori.post@northwestern.edu

\section{Abstract}

Background: SARS-CoV-2, the virus that caused the global COVID-19 pandemic, has severely impacted Central Asia; in spring 2020, high numbers of cases and deaths were reported in this region. The second wave of the COVID-19 pandemic is currently breaching the borders of Central Asia. Public health surveillance is necessary to inform policy and guide leaders; however, existing surveillance explains past transmissions while obscuring shifts in the pandemic, increases in infection rates, and the persistence of the transmission of COVID-19.

Objective: The goal of this study is to provide enhanced surveillance metrics for SARS-CoV-2 transmission that account for weekly shifts in the pandemic, including speed, acceleration, jerk, and persistence, to better understand the risk of explosive growth in each country and which countries are managing the pandemic successfully.

Methods: Using a longitudinal trend analysis study design, we extracted 60 days of COVID-19-related data from public health registries. We used an empirical difference equation to measure the daily number of cases in the Central Asia region as a function of the prior number of cases, level of testing, and weekly shift variables based on a dynamic panel model that was estimated using the generalized method of moments approach by implementing the Arellano-Bond estimator in R.

Results: COVID-19 transmission rates were tracked for the weeks of September 30 to October 6 and October 7-13, 2020, in Central Asia. The region averaged 11,730 new cases per day for the first week and 14,514 for the second week. Infection rates increased across the region from 4.74 per 100,000 persons to 5.66. Russia and Turkey had the highest 7-day moving averages in the region, with 9836 and 1469, respectively, for the week of October 6 and 12,501 and 1603, respectively, for the week of October 13. Russia has the fourth highest speed in the region and continues to have positive acceleration, driving the negative trend for the entire region as the largest country by population. Armenia is experiencing explosive growth of COVID-19; its infection rate of 13.73 for the week of October 6 quickly jumped to 25.19, the highest in the region, the following week. The region overall is experiencing increases in its 7-day moving average of new cases, infection, rate, and speed, with continued positive acceleration and no sign of a reversal in sight.

Conclusions: The rapidly evolving COVID-19 pandemic requires novel dynamic surveillance metrics in addition to static metrics to effectively analyze the pandemic trajectory and control spread. Policy makers need to know the magnitude of transmission 
rates, how quickly they are accelerating, and how previous cases are impacting current caseload due to a lag effect. These metrics applied to Central Asia suggest that the region is trending negatively, primarily due to minimal restrictions in Russia.

(J Med Internet Res 2021;23(2):e25799) doi: 10.2196/25799

\section{KEYWORDS}

SARS-CoV-2 surveillance; second wave; wave two; global COVID-19 surveillance; Central Asia public health surveillance; Central Asia COVID-19; Central Asia surveillance metrics; dynamic panel data; generalized method of moments; Central Asia econometrics; Central Asia SARS-CoV-2; Central Asia COVID-19 surveillance system; Central Asia COVID-19 transmission speed; Central Asia COVID transmission acceleration; COVID-19 transmission deceleration; COVID-19 transmission jerk; COVID-19 7-day lag; SARS-CoV-2; Arellano-Bond estimator, generalized method of moments; GMM; Armenia; Azerbaijan; Cyprus; Faeroe Islands; Georgia; Gibraltar; Kazakhstan; Kosovo; Kyrgyzstan; Macedonia; Russia; Tajikistan Turkey; Turkmenistan; Uzbekistan; COVID-19; surveillance; longitudinal; trend; trend analysis; monitoring; public health; infectious disease; transmission; risk; management; policy; prevention

\section{Introduction}

\section{Background}

On December 29, 2019, 4 cases of "pneumonia of unknown etiology" were reported in Wuhan, Hubei Province, China [1]. What began as 4 isolated cases escalated into a global pandemic of SARS-CoV-2, the virus that causes COVID-19. To date, the caseload has reached 68,645,081 confirmed cases, and 1,564,496 deaths have been confirmed globally [2]. Nations have been greatly impacted by the pandemic, which has resulted in significant morbidity and mortality, food insecurity, and an economic recession that has not bottomed out. Global leaders are struggling to balance disease control with salvaging their plummeting economies in the face of a global pandemic [3]. This study aims to examine where and when SARS-CoV-2 was transmitted in Central Asia within the context of a global pandemic by delving into the environmental, sociocultural, and public health characteristics of COVID-19. For the purposes of this study, we use the World Bank's definition of Central Asia, which includes Armenia, Azerbaijan, Cyprus, Faeroe Islands, Georgia, Gibraltar, Kazakhstan, Kosovo, Kyrgyzstan, Macedonia, Russia, Tajikistan, Turkey, Turkmenistan, and Uzbekistan [4].

\section{History of Central Asia}

Central Asia is largely composed of nation states that are former Soviet Union member countries. The Union of Soviet Socialist Republics (USSR) was dissolved in 1991 after controlling the region for 68 years, following a coup d'état during President Gorbachev's administration. The former Soviet Union left a lasting legacy in the former national republics [5]. The USSR shifted from a centralized government and systems to independent states. Many essential institutions, such as national currency systems and military forces, were developed from the ground up. Many of these fledgling nations failed to achieve democracies, which led to more chaos and conflict. The "colored revolutions" from 1999-2005, a series of mass protests and riots, lead to the overthrow of the semiauthoritarian regimes in Serbia, Georgia, Ukraine, and Kyrgyzstan [6].

Public health systems in these new nations in Central Asia faced many challenges, including endemic infectious diseases [7] such as tuberculosis, HIV, and substance use disorders [8,9]. Alcohol poisoning is relatively common in the former USSR
[10], contributing to low life expectancy in Russia [11,12]. Central Asia has one of the highest prevalence rates of tobacco misuse [13]. Misuses of alcohol, tobacco, and other substances represent both direct and indirect COVID-19 risk factors. Drinking alcohol, smoking, and misusing substances increases a person's risk of being infected with SARS-CoV-2 and having worse outcomes if infected [14-17]. Moreover, persons who are self-isolating are at higher risk of substance use disorders [18-20]. Substance use disorders also contribute to increases chronic disease [21-23]. During past epidemics, reduced access to medical care for individuals with serious illness, such as HIV or tuberculosis, resulted in more deaths from complications due to a lack of health care resources $[24,25]$.

\section{Food and Water Security}

Progress in food security [26] has stalled in Central Asia in recent years, with growth in malnourished and undernourished populations [27]. Malnourishment is a function of poverty $[28,29]$.

Food insecurity is linked to environmental conditions caused by overuse of the Aral Sea, which has been depleted by $90 \%$ since 1960 to irrigate large areas of land [30,31]. Safe water is not available for 22 million people ( $31 \%$ of the population) throughout Kazakhstan, Kyrgyzstan, Uzbekistan, Tajikistan, and Turkmenistan. The majority of the affected individuals live in rural areas, where there are limited sewer connections and septic tanks [32]. People living near the highly polluted Aral Sea have higher levels of tuberculosis, anemia, and cancer, and they may be at higher risk of debilitating SARS-CoV-2 infection [33].

Beyond access to food, obesity is becoming more pervasive [34] as Central Asian foods mirror the "Western diet" of high fat and low grains [26]. Traditional dishes have high contents of sodium, likely due to the "Silk Road" pattern in which countries along the former Silk Road, a trade route through Central Asia established in the second century BC [35,36], use large quantities of salt for food preservation [37]. Obesity also contributes to chronic metabolic diseases and is associated with worse outcomes in those infected with SARS-CoV-2 [38].

\section{Current Politics}

Because Kazakhstan and China share a border, preventative measures in Kazakhstan were established as early as January 
6, 2020, enforcing increased border sanitation and monitoring arrivals from China [39]. The first cases of COVID-19 in Kazakhstan, discovered in people arriving from Germany and Italy, were recorded on March 13. A state of emergency was announced on March 16; schools converted to remote learning, and quarantines were established in some areas as early as March 19 [39].

Many countries in the region have had disruptions in the labor market. The oil economies in Kazakhstan and Azerbaijan have been negatively impacted [40]. Tajikistan has experienced rising unemployment [29], and the poverty rate has risen across Central Asia [41-46].

State governments have attempted to minimize the impact of the virus; complaints about lack of adequate personal protective equipment in Russia were suppressed [47], medical authorities who gave public health advice in Turkey were criminally investigated [48], and the oppressive Turkmenistan government denied the existence of even a single case of SARS-CoV-2 [49].

In the electoral authoritarian regime of Azerbaijan, lockdown was established immediately following the first confirmed case of SARS-CoV-2 on February 28. The capital of Azerbaijan instated highly restrictive rules and shut down its border with the Islamic Republic of Iran, where cases were spreading quickly, the next day [50].

In Azerbaijan, violations of the quarantine mandate were punishable by fines, custodial restraint, and prison time [51]. Severe rules were briefly in place; people aged over 65 years were prohibited from leaving their homes [50], and citizens were required to send an SMS text message to a government telephone number to request permission to leave their home for up to three hours. The government inactivated the cellular service of political rivals so that they could not request permission to leave their residences and thus were confined to their homes [51]. The pandemic has been exploited as a means to restrict individual human rights in other countries as well; government access to private cell phone data was allowed in Armenia [52], and protests were restricted in Russia [53]. In both Uzbekistan and Tajikistan [54], penalties were introduced for the spread of false information about the virus through the media.

While Azerbaijan initially slowed the spread of the virus [55] and relaxed restrictions in May, the strict quarantine regime was reinstated in four major cities on June 21, 2020, after a surge in cases.

Shocking the international community, Russian President Vladimir Putin announced on August 11 that their country's health regulator was the first in the world to approve a SARS-CoV-2 vaccine for mass use [56]. This approval has been criticized as unsafe because the standard phase III clinical trials for new drugs were not completed at the time of his announcement [57]. While Russia's first approved vaccine, known as "Sputnik V," was still undergoing phase III trials, on October 14, President Putin announced the approval of a second SARS-CoV-2 vaccine [58]. Without adequate testing, we do not know the possible detrimental side effects of these vaccines, which may undermine attempts by the international community to provide safe immunization [56].

Other than vaccine efforts, Russia has not implemented significant public health measures. During the first wave of infections in March 2020, no financial support was given to small or medium-sized businesses despite instructions for employees to stay home on paid leave [59]. However, in mid-April, it was announced that over 100 billion rubles (US $\$ 1.325$ billion) would be allocated to support small and medium-sized businesses [54]. The number of active cases in Russia reached a peak of 245,580 on June 15 and then began to decline [60]. With the second wave of infections in October after loosening restrictions, Russia saw a spike in cases and reported the fourth highest number of SARS-CoV-2 cases worldwide, behind the United States, India, and Brazil [61]. Russia reported a record number of 29,039 active cases on December 6 [60]. Despite record numbers of daily cases, with 26,097 new cases on December 8 for a total of 2,541,199 cases, protective measures continued to be rolled back. While gloves and masks are required in the Moscow metro, citizens must register their telephone number before entering a bar or nightclub; moreover, museums are closed, international flights are gradually being reinstated, and students in first through fifth grade are returning to school [62]. As early as July, the mayor of Moscow announced that wearing masks would no longer be required outdoors as new COVID-19 cases dwindled in the capital [54]. Figure 1 shows the timeline of the COVID-19 pandemic from December 2019 to October 2020 in Central Asia.

Without an effective vaccine to prevent COVID-19, Central Asian leaders require an effective SARS-CoV-2 surveillance system that enables their governments to make safe and informed decisions [63-70]. Public health departments [71-76] plus several universities [77] and media outlets [78,79] are tracking the novel coronavirus using raw data regarding the number of new infections, testing, positivity, basic reproduction number $\left(\mathrm{R}_{0}\right)$, and deaths, among other measures, such as local hospital capacity.

Figure 1. Timeline of the COVID-19 pandemic in Central Asia.

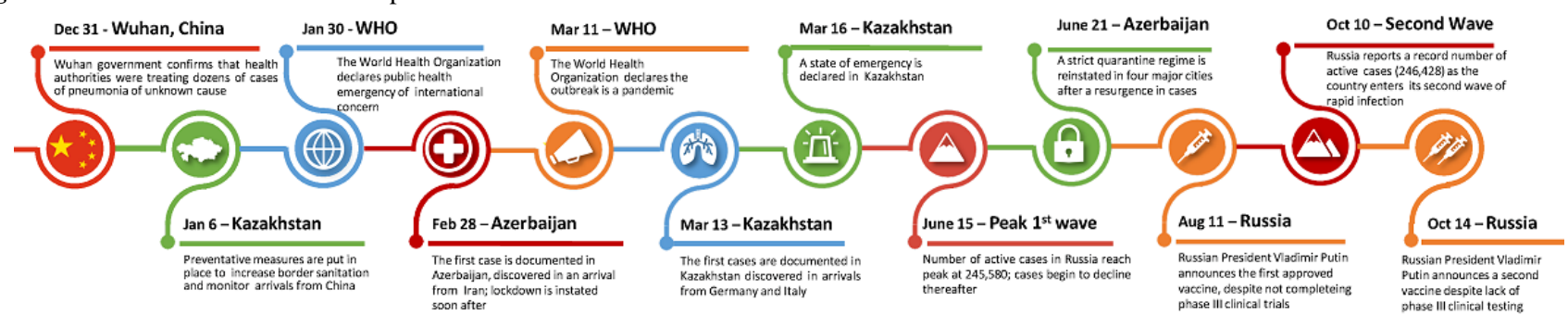


To that end, the objective of our research was to use a longitudinal trend analysis study design in concert with dynamic panel modeling and method of moments approaches to correct for existing surveillance data limitations [80,81]. Specifically, we measured significant weekly shifts in the increase, decrease, or plateaued transmission of SARS-CoV-2. Our study measured the underlying causal effect from the previous week that persisted through the current week, with a 7-day persistence rate to explain a clustering or declustering effect. The 7-day persistence represents an underlying disease transmission wave, where a large number of transmissions that resulted in a large number of infections on 1 day then "echoes" forward into a large number of new transmissions and hence a large number of new cases in the next 7 days. An example of the 7-day lag would be large sporting events in the United Kingdom that drew large crowds over an extended period of time even after cases were confirmed in the country. Other potential "super-spreader" events occurred in Turkmenistan, when a mass cycling rally was held on April 7 to celebrate World Health Day [82]. In summary, we measured negative and positive shifts in the transmission of SARS-CoV-2 or its acceleration and deceleration rates. We measured negative and positive shifts in the transmission of SARS-CoV-2 as well as the speed, acceleration or deceleration, and jerk rates along with the 7-day persistence, which do not suffer from sampling bias. For details, see Oehmke et al $[80,81]$. Our surveillance metric will provide public health surveillance data to inform governments that are making decisions regarding disease control, mitigation strategies, and reopening policies as they continue to manage this unprecedented situation.

\section{Methods}

This study relies on a longitudinal trend analysis of data collected from the Foundation for Innovative New Diagnostics (FIND) [83]. FIND compiles data from multiple sources across individual websites, statistical reports, and press releases. Data for the most recent 8 weeks were accessed from a GitHub repository that compiles data from multiple sources on the web; data for the most recent 4 weeks were accessed from the GitHub repository [84]. This resulted in a panel of 14 countries in Central Asia with 47-50 days in each panel $(\mathrm{N}=696)$. An empirical difference equation was specified in which the number of new positive cases in each country at each day is a function of the prior number of cases, the level of testing, and weekly shift variables that measure whether the contagion was growing faster than, the same as, or slower than in the previous weeks. This resulted in a dynamic panel model that was estimated using the generalized method of moments approach by implementing the Arellano-Bond estimator in R (R Project) [85].

Arellano-Bond estimation of difference equations has several statistical advantages: (1) it enables statistical examination of the predictive ability of a model and the validity of the model specification; (2) it corrects for autocorrelation and heteroscedasticity; (3) it has good properties for handling data with a small number of time periods and large number of states; and (4) it corrects for omitted variables and provides a statistical test of correction validity. With these advantages, the method is applicable to ascertaining and statistically validating changes in the evolution of the pandemic within a period of $\leq 1$ week, such as changes in the reproduction rate. See Oehmke et al $[80,81]$ for a detailed discussion of the methods. Finally, we calculated these indicators to inform public health leaders of where to take corrective action at a local level. China enjoyed great success at controlling the pandemic by closing down smaller geographical regions, preserving the larger economy and preventing other adverse outcomes from a national quarantine.

\section{Results}

\section{Country Regression Results}

We analyzed the 12 countries that are included in the Central Asia region as defined by the World Bank. The results of the associated regression supporting the weekly surveillance metrics are captured in Table 1. The Wald statistic for regression was significant $\left(\chi_{7}^{2}=14,217, P<.001\right)$. The Sargan statistic for validity was insignificant $\left(\chi_{550}^{2}=9, P>.99\right)$ and failed to reject the validity of overidentifying restrictions.

As shown in Table 1, the 1-day lag coefficient is positive and significant $(1.075, P<.001)$, suggesting a clustering effect where the number of cases on a given day impact the number of cases on adjoining days. The 7-day lag coefficient and the impact of the limited testing over the weekend on case counts (the "weekend effect") are both insignificant. The shift parameters for the weeks of October 6 and 13 are also insignificant, suggesting that there were no major changes in the rate of disease transmission in the region between these 2 weeks in general. The coefficient for cumulative tests is insignificant. 
Table 1. Arellano-Bond dynamic panel data modeling of the number of daily infections reported by country in Central Asia from September 30 to October 13, 2020.

\begin{tabular}{lll}
\hline Variable & Values & $P$ value \\
\hline 1-day lag coefficient & 1.075 & $<.001$ \\
7-day lag coefficient & -0.051 & .89 \\
Cumulative tests & 0.000016 & .55 \\
Shift parameter, week of October 6 & -0.157 & .53 \\
Shift parameter, week of October 13 & -0.417 & .12 \\
Weekend effect $^{\mathrm{a}}$ & -0.009 & .99 \\
\hline
\end{tabular}

${ }^{\mathrm{a}}$ Weekend effect: impact of limited testing over the weekend on case counts.

\section{Interpretation: Central Asian Regression Results}

The 7-day lag and shift parameters suggest that there have been no recent changes in disease transmission rates. Additionally, there is no weekend effect or cumulative test effect.

\section{Surveillance Results}

Static and dynamic surveillance metrics for the weeks of October 6 and 13 are reflected in Tables 2-6, and Table 7 shows the most populous countries in Central Asia as of 2020. Tables 2 and 3 capture static metrics, including the number of new COVID-19 cases, number of cumulative COVID-19 cases, 7-day moving average of new cases, rate of infection, new deaths, cumulative deaths, 7-day moving average of number of deaths, and death rates. Novel dynamic metrics are reflected in Tables 4 and 5 . These metrics include (1) speed, or the weekly average of new daily cases per 100,000 persons, (2) acceleration, or the day-to-day change in speed, (3) jerk, or the week-over-week change in acceleration, 4) 7-day persistence effect, or the number of new cases per 100,000 persons reported on a particular day that are associated with new cases reported 7 days previously. These novel metrics enable analysis of the impact of previous cases on current cases and identification of potential changes of the pandemic trajectory in the future.

Table 2 reflects static surveillance metrics for the week of September 30 to October 6, and Table 3 reflects those metrics for the week of October 7-13. The region averaged 11,730 new cases per day for the period ending on October 6 and 14,514 for the period ending on October 13. The infection rate increased across the region from 4.74 per 100,000 persons to 5.66. This increase in infection rate was accompanied by a slight increase in death rate from 0.09 per 100,000 persons to 0.11 . Up to October 13 , the region had reported 2,040,812 cumulative COVID-19 cases.

Table 2. Static surveillance metrics for the week of September 30 to October 6, 2020.

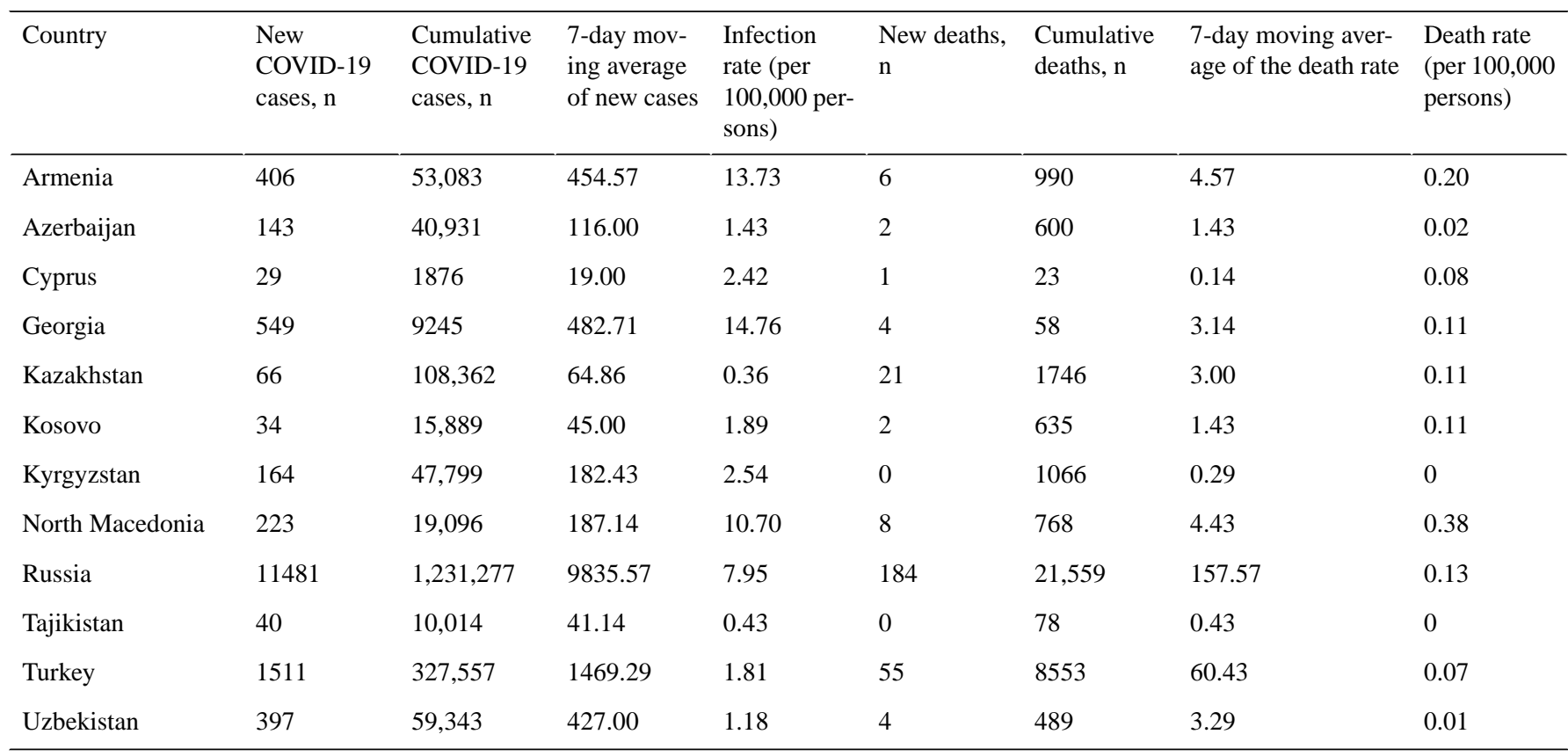


Table 3. Static surveillance metrics for the week of October 7-13, 2020.

\begin{tabular}{|c|c|c|c|c|c|c|c|c|}
\hline Country & $\begin{array}{l}\text { New } \\
\text { COVID-19 } \\
\text { cases, n }\end{array}$ & $\begin{array}{l}\text { Cumulative } \\
\text { COVID-19 } \\
\text { cases, } \mathrm{n}\end{array}$ & $\begin{array}{l}\text { 7-day mov- } \\
\text { ing average } \\
\text { of new cases }\end{array}$ & $\begin{array}{l}\text { Infection } \\
\text { rate (per } \\
100,000 \text { per- } \\
\text { sons) }\end{array}$ & $\begin{array}{l}\text { New deaths, } \\
\mathrm{n}\end{array}$ & $\begin{array}{l}\text { Cumulative } \\
\text { deaths, } \mathrm{n}\end{array}$ & $\begin{array}{l}\text { 7-day moving aver- } \\
\text { age of the death rate }\end{array}$ & $\begin{array}{l}\text { Death rate } \\
\text { (per } 100,000 \\
\text { persons) }\end{array}$ \\
\hline Armenia & 745 & 57,566 & 640.43 & 25.19 & 6 & 1032 & 6.00 & 0.20 \\
\hline Azerbaijan & 277 & 42,381 & 207.14 & 2.76 & 3 & 612 & 1.71 & 0.03 \\
\hline Cyprus & 83 & 2130 & 36.29 & 6.92 & 0 & 25 & 0.29 & 0.00 \\
\hline Georgia & 569 & 12,841 & 513.71 & 15.29 & 9 & 102 & 6.29 & 0.24 \\
\hline Kazakhstan & 83 & 108,984 & 88.86 & 0.45 & 22 & 1768 & 3.14 & 0.12 \\
\hline Kosovo & 98 & 16,345 & 65.14 & 5.46 & 1 & 649 & 2.00 & 0.06 \\
\hline Kyrgyzstan & 343 & 49,871 & 296.00 & 5.31 & 2 & 1092 & 3.71 & 0.03 \\
\hline North Macedonia & 80 & 21,193 & 299.57 & 3.84 & 3 & 800 & 4.57 & 0.14 \\
\hline Russia & 13,690 & $1,318,783$ & $12,500.86$ & 9.48 & 240 & 22,834 & 182.14 & 0.17 \\
\hline Tajikistan & 37 & 10,297 & 40.43 & 0.40 & 0 & 79 & 0.14 & 0.00 \\
\hline Turkey & 1632 & 338,779 & 1603.14 & 1.96 & 62 & 8957 & 57.71 & 0.07 \\
\hline Uzbekistan & 323 & 61,642 & 328.43 & 0.96 & 2 & 511 & 3.14 & 0.01 \\
\hline
\end{tabular}

Table 4. Novel surveillance metrics for the week of September 30 to October 6, 2020.

\begin{tabular}{|c|c|c|c|c|}
\hline Country & Speed $^{\mathrm{a}}$ & Acceleration $^{\mathrm{b}}$ & Jerk $^{\mathrm{c}}$ & 7-day persistence effect on speed ${ }^{\mathrm{d}}$ \\
\hline Armenia & 15.4 & 0.4 & 0.3 & -0.6 \\
\hline Azerbaijan & 1.2 & 0.1 & 0 & -0.1 \\
\hline Cyprus & 1.6 & 0 & -0.1 & -0.1 \\
\hline Georgia & 13.0 & 0.9 & -0.2 & -0.4 \\
\hline Kazakhstan & 0.4 & 0 & 0 & 0 \\
\hline Kosovo & 2.5 & -0.2 & -0.1 & -0.1 \\
\hline Kyrgyzstan & 2.8 & 0 & -0.2 & -0.1 \\
\hline North Macedonia & 9.0 & 0.8 & 0.5 & -0.3 \\
\hline Russia & 6.8 & 0.3 & 0.1 & -0.3 \\
\hline Tajikistan & 0.4 & 0 & 0.0 & 0 \\
\hline Turkey & 1.8 & 0 & 0.0 & -0.1 \\
\hline Uzbekistan & 1.3 & -0.1 & 0.0 & -0.1 \\
\hline
\end{tabular}

${ }^{\text {a }}$ Speed: daily positives per 100,000 persons (weekly average of new daily cases per 100,000 persons).

${ }^{\mathrm{b}}$ Acceleration: day-to-day change in the number of positives per day (weekly average per 100,000 persons).

c Jerk: week-over-week change in acceleration per 100,000 persons.

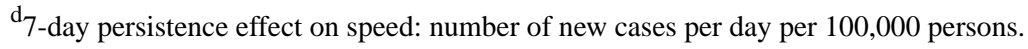


Table 5. Novel surveillance metrics for the week of October 7-13, 2020.

\begin{tabular}{lllll}
\hline Country & Speed $^{\mathrm{a}}$ & Acceleration $^{\mathrm{b}}$ & Jerk $^{\mathrm{c}}$ & 7-day persistence effect on speed $^{\mathrm{d}}$ \\
\hline Armenia & 21.7 & 1.6 & 0.7 & -0.8 \\
Azerbaijan & 2.1 & 0.2 & 0.2 & -0.1 \\
Cyprus & 3.0 & 0.6 & 0.4 & -0.1 \\
Georgia & 13.8 & 0.1 & 0.5 & -0.7 \\
Kazakhstan & 0.5 & 0 & 0 & 0 \\
Kosovo & 3.6 & 0.5 & 0.3 & -0.1 \\
Kyrgyzstan & 4.6 & 0.4 & 0.2 & -0.1 \\
North Macedonia & 14.4 & -1.0 & -1.6 & -0.5 \\
Russia & 5.2 & 0.1 & 0.0 & -0.2 \\
Tajikistan & 8.7 & 0.2 & 0.0 & -0.4 \\
Turkey & 0.4 & 0 & 0.0 & 0 \\
Uzbekistan & 1.9 & 0 & 0.0 & -0.1 \\
\hline
\end{tabular}

${ }^{a}$ Speed: daily positives per 100,000 persons (weekly average of new daily cases per 100,000 persons).

${ }^{\mathrm{b}}$ Acceleration: day-to-day change in the number of positives per day (weekly average per 100,000 persons).

${ }^{\mathrm{c}}$ Jerk: week-over-week change in acceleration per 100,000 persons.

${ }^{\mathrm{d}} 7$-day persistence effect on speed: number of new cases per day per 100,000 persons.

Table 6. Comparison of 1-day persistence in the four countries in Central Asia with positive significant positive accelerations for the week of October $6,2020$.

\begin{tabular}{lll}
\hline Country & $\begin{array}{l}\text { 1-day persistence } \\
\text { Week of September 30 }\end{array}$ & Week of October 6 \\
\hline Armenia & 16.1 & 21.5 \\
Georgia & 13.0 & 16.5 \\
North Macedonia & 8.8 & 14.8 \\
Russia & 7.0 & 9.1 \\
\hline
\end{tabular}

Table 7. Most populous countries in Central Asia as of 2020.

\begin{tabular}{ll}
\hline Country & Population as of 2020, n \\
\hline Russia & $145,953,632$ \\
Turkey & $84,621,255$ \\
Uzbekistan & $33,469,203$ \\
Kazakhstan & $18,776,707$ \\
\hline
\end{tabular}

Russia and Turkey had the highest 7-day moving averages in the region, at 9836 and 1469, respectively, for the week of October 6, and 12,501 and 1603, respectively, for the week of October 13 (Tables 2 and 3). In terms of infection rate, accounting for population, Russia was at 7.95 per 100,000 persons and Turkey was at 1.81 for the week of October 06. The countries that had the highest infection rates in the region included Georgia, at 14.76 per 100,000 persons, and Armenia, at 13.73. For the following week, the infection rate in Armenia jumped to the highest in the region, at 25.19 per 100,000 persons, while Georgia had a very slight increase to 15.29 . Kazakhstan had the lowest infection rate in the region, at 0.36 per 100,000 persons for the week of October 6 .
Russia and Turkey also had the highest 7-day moving averages of deaths in the region, with Russia at 157.57 per 100,000 persons for the week of October 6 and Turkey at 60.43 . Together, they accounted for approximately $90 \%$ of the deaths reported in the region. Up to October 13, the region had reported 38,461 cumulative deaths. For the week of 10/06, North Macedonia and Armenia had the highest death rates per 100,000 persons in the region, at 0.38 and 0.20 , respectively. Armenia maintained a death rate of 0.20 per 100,000 persons the following week. Georgia had the highest death rate the week of $10 / 13$ at 0.24 per 100,000 persons, up from 0.11 the previous week. 
The 1-day persistence is an indicator of a clustering effect where an event on a particular day causes an increase in the number of cases on adjoining days. As shown in Table 6, the 1-day persistence was highest in Armenia at 16.1, and it increased to 21.5 the following week. North Macedonia saw a large increase from 8.8 to 16.5, with Georgia and Russia seeing smaller increases from 13.0 to 14.8 and 7.0 to 9.1 , respectively.

Largely consistent with infection rates, Armenia, Georgia, and North Macedonia had the highest speed or average of new daily cases per 100,000 persons. During the week of October 6, Armenia had a speed of 15.4 , increasing to 21.7 the following week. Georgia had a speed of 13.0, which increased slightly the following week to 13.8. North Macedonia had a speed of 9.0, which increased to 14.4. The region overall had an increase in speed from 4.2 to 5.2 .

Speed is best used in conjunction with acceleration and jerk, which can provide further insight into potential pandemic trajectory changes. Four countries in the region had significant positive accelerations for the week of October 6: Georgia at 0.9, North Macedonia at 0.8, Armenia at 0.4, and Russia at 0.3. North Macedonia, Armenia, and Russia also had positive jerks. During the following week, in addition to the highest speed, Armenia had the highest acceleration and jerk in the region. Figure 2 shows shows weekly trends of SARS-CoV-2 in Central Asia [86], and additional trends can be found in Multimedia Appendices 1-5.

Figure 2. Weekly SARS-CoV2 trends in Central Asia [86].

First Day of Week

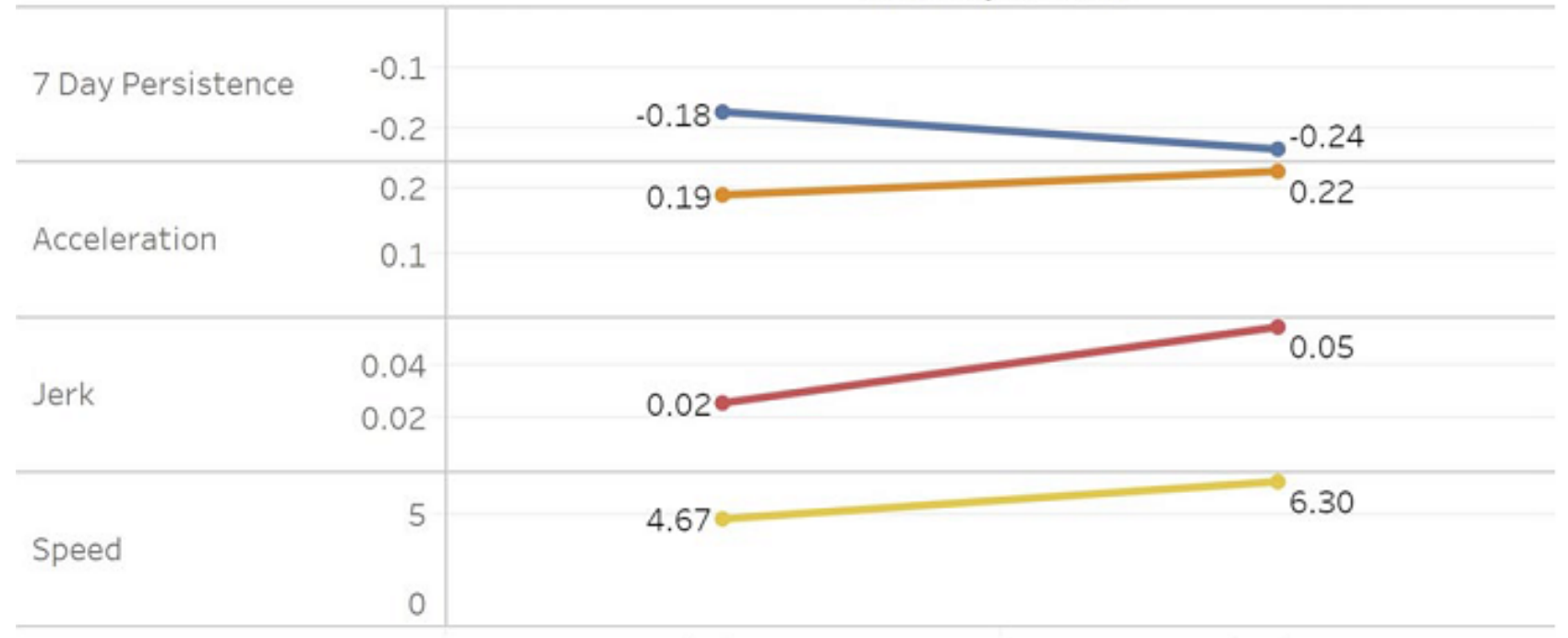

$10 / 6 / 2020$

$10 / 13 / 2020$

\section{Discussion}

\section{Principal Results}

COVID-19 poses a significant threat to the Central Asian region, which is largely composed of former Soviet republics. These countries continue to suffer from food insecurity, high levels of poverty, and variation in health care quality and access as the region continues on its journey of transitioning from a centralized Soviet medical system. The population also suffers from multiple endemic infections, such as HIV/AIDS and tuberculosis. Russia and Turkey comprise the bulk of the population in Central Asia, and these countries are facing growing burdens of chronic disease and some of the highest obesity rates in Europe. Due to the combination of these factors, the region is vulnerable to negative outcomes from the COVID-19 pandemic. To date, the region has seen variations in policy intervention to control the spread of COVID-19 and mitigate outbreaks. Some countries, such as Kazakhstan and Azerbaijan, imposed strict and early lockdowns, while others, such as Russia, imposed more limited interventions.

Metrics tracking the progression of COVID-19 in Central Asia to date have largely been static, including measures such as new

cases, cumulative cases, deaths, and 7-day moving averages. These metrics provide a view of the current state of the pandemic but are unable to provide any insight into the change in the speed of the pandemic over time or potential shifts in its trajectory, evolving from controlled spread to rapid growth or vice versa. These metrics also provide limited utility in comparing countries to each other and in analyzing countries with smaller populations. Novel metrics such as speed, acceleration, and jerk help contextualize static metrics and provide a view of trajectory over time, enabling potential anticipation of how the pandemic will evolve in the future.

Considering the static and dynamic metrics, it is apparent that the Central Asian region is trending negatively. The region saw an increase in 7-day moving average of new cases, infection rate, and speed for the week of October 13 compared to the week of October 6, with continued positive acceleration. This trend is largely driven by Russia and Turkey, which together encompass over $70 \%$ of the region's population and showed the highest 7-day moving averages in the region. Russia has the fourth highest speed in the region and continues to experience positive acceleration.

Kazakhstan, the fourth most populous country in the region, had the lowest infection rate for the week of October 6. This is 
likely due to a continued emphasis on policy interventions to curb the spread of COVID-19. Authorities in Kazakhstan took some of the earliest precautions to prevent infections and continue to strictly enforce pandemic mitigation measures, including halting the easing of restrictions due to the global spike in COVID-19 cases in recent weeks.

Turkey, while contributing a significant portion of the total cases in the region due to its population size, has maintained relatively low infection rates of 1.81 and 1.96 per 100,000 persons for the weeks of October 6 and 13, respectively. Turkey has taken significant precautions to mitigate the spread of the virus, and authorities continue to enforce rigorous mask wearing and social distancing guidelines along with local quarantines when necessary.

Armenia is experiencing uncontrolled spread of COVID-19, with an infection rate of 13.73 per 100,000 persons for the week of October 6 quickly jumping to 25.19 , the highest in the region, the following week. The pandemic speed, consistent with the infection rate trajectory, increased from 15.4 to 21.7 , with an acceleration increase from 0.4 to 1.6 . This change is likely due to the recent lifting of the COVID-19 state of emergency, which allowed the resumption of in-person schooling and international flights, among other activities.

After Armenia, Georgia and Russia had the highest infection rates in the region for the week of October 13. Russia continues to resist implementing interventions to curb the spread of COVID-19, with no mask mandates, capacity caps, or nightlife restrictions. In addition to the significant focus on developing an effective vaccine, there has been limited intervention to manage the spread of COVID-19 in Russia. This policy stance is impacting the trajectory of the region, which is trending negatively with no sign of a reversal in sight.

\section{Conclusion}

The rapid evolution, novel outbreaks, and frequently fluctuating trajectory of COVID-19 cannot be adequately assessed using static public health measures alone. Static measures, including the number of new COVID-19 cases, number of cumulative COVID-19 cases, 7-day moving average of new cases, rate of infection, number of new deaths, number of cumulative deaths, 7-day moving average of number of deaths, and death rates, provide a current view of the state of the pandemic. However, these measures do not provide any insight into how the trajectory of the pandemic may change over time.

Generally, the approach to modeling the spread of COVID-19 is to assume there is an underlying contagion model [87] and then to attempt to measure those model parameters [88], which involves contact tracing to determine the spread of the disease [89-92]. With an incubation period of up to 14 days [93], modeling this spread can take months. Early estimates of COVID-19 were developed using the method by Lipsitch et al [94], which was used for contact tracing in Wuhan and Italy; however, the statistical properties were weak [95-100]. Zhao et al [96] estimated the serial interval distribution and $R_{0}$ based on only 6 pairs of cases, which is insufficient to understand the transmission of COVID-19 [101]. This results in relaxing of the assumptions in these models, such as disaggregating the population by geography and modeling within-geography and across-geography personal interactions [102]. Martcheva [103] developed a dynamic model from several contagion models and their possible dynamics [104,105]. They are limited to the statistical inference of parameter values from actual data [106].

Novel surveillance metrics allow for a more nuanced analysis of the COVID-19 pandemic and together with static metrics, can enable policymakers to make informed decisions to control the spread of the pandemic and prevent further outbreaks. Novel dynamic metrics include speed, acceleration, jerk, and 7-day persistence, and they provide potential insight into how the pandemic will evolve in the future.

The analysis of Central Asia using static and novel surveillance metrics suggests that the region is precariously positioned and trending negatively. Russia, the largest country by population, continues to have high infection rates and one of the highest speeds of infection. With no sign of increasing restrictions, it is unlikely that this trend will reverse and that outbreaks in the region will be controlled.

\section{Limitations}

Our data are limited by reporting methods across individual countries. Some countries, such as Turkmenistan, refuse to acknowledge COVID-19 cases. Variation in testing and infrastructure may impact the number of cases reported by other countries. The data are reported at a national level, which does not enable any subnational analysis.

\section{Comparison to Prior Work}

This study is part of a broader research program at Northwestern Feinberg School of Medicine (The Global SARS-CoV-2 Surveillance Project: Policy, Persistence, \& Transmission). Novel surveillance metrics, including speed, acceleration, jerk, and 7-day persistence, have been developed by this research program and are being applied to all global regions.

\section{Acknowledgments}

This publication was made possible through support provided by Feed the Future through the US Agency for International Development under the terms of Contract No. 7200LA1800003. The opinions expressed herein are those of the authors and do not necessarily reflect the views of the US Agency for International Development.

\section{Conflicts of Interest}

None declared. 


\section{Multimedia Appendix 1}

Weekly Cental Asia SARS-CoV-2 statistics by country.

[PNG File , 154 KB-Multimedia Appendix 1]

\section{Multimedia Appendix 2}

Weekly Central Asia 7-day persistence map.

[PNG File, 372 KB-Multimedia Appendix 2]

\section{Multimedia Appendix 3}

Weekly Central Asia statistics.

[PNG File, 199 KB-Multimedia Appendix 3]

\section{Multimedia Appendix 4}

Weekly Central Asia jerk map.

[PNG File, 359 KB-Multimedia Appendix 4]

\section{Multimedia Appendix 5}

Weekly Central Asia acceleration jerk map.

[PNG File , 434 KB-Multimedia Appendix 5]

\section{References}

1. Li Q, Guan X, Wu P, Wang X, Zhou L, Tong Y, et al. Early transmission dynamics in Wuhan, China, of novel coronavirus-infected pneumonia. N Engl J Med 2020 Mar 26;382(13):1199-1207 [FREE Full text] [doi: 10.1056/NEJMoa2001316] [Medline: 31995857]

2. COVID-19 Dashboard by the Center for Systems Science and Engineering (CSSE) at Johns Hopkins University (JHU). Johns Hopkins Coronavirus Resource Center. URL: https://coronavirus.jhu.edu/map.html [accessed 2020-12-09]

3. McKee M, Stuckler D. If the world fails to protect the economy, COVID-19 will damage health not just now but also in the future. Nature Medicine. 2020 ;26(5):640-642.

4. The World Bank in Europe and Central Asia. The World Bank. URL: https://www.worldbank.org/en/region/eca [accessed 2020-08-10]

5. Collapse of the Soviet Union. Encyclopaedia Britannica. URL: https://www.britannica.com/event/ the-collapse-of-the-Soviet-Union\#ref1258663 [accessed 2021-01-25]

6. D'Anieri P. Explaining the success and failure of post-communist revolutions. CPCS 2006;39(3):331-350. [doi: 10.1016/j.postcomstud.2006.06.002]

7. Adambekov S, Kaiyrlykyzy A, Igissinov N, Linkov F. Health challenges in Kazakhstan and Central Asia. J Epidemiol Community Health 2016;70(1):104-108. [Medline: 26254293]

8. Schluger NW, El-Bassel N, Hermosilla S, Terlikbayeva A, Darisheva M, Aifah A, et al. Tuberculosis, drug use and HIV infection in Central Asia: an urgent need for attention. Drug Alcohol Depend 2013 Nov;132 Suppl 1:S32-S36. [doi: 10.1016/j.drugalcdep.2013.07.012] [Medline: 23928052]

9. Altice FL, Azbel L, Stone J, Brooks-Pollock E, Smyrnov P, Dvoriak S, et al. The perfect storm: incarceration and the high-risk environment perpetuating transmission of HIV, hepatitis C virus, and tuberculosis in Eastern Europe and Central Asia. Lancet 2016 Sep;388(10050):1228-1248. [doi: 10.1016/s0140-6736(16)30856-x]

10. Stickley A, Leinsalu M, Andreev E, Razvodovsky Y, Vågerö D, McKee M. Alcohol poisoning in Russia and the countries in the European part of the former Soviet Union, 1970 2002. Eur J Public Health 2007 Oct 27;17(5):444-449. [doi: 10.1093/eurpub/ck1275] [Medline: 17327281]

11. Leon DA, Chenet L, Shkolnikov VM, Zakharov S, Shapiro J, Rakhmanova G, et al. Huge variation in Russian mortality rates 1984-94: artefact, alcohol, or what? Lancet 1997 Aug;350(9075):383-388. [doi: 10.1016/s0140-6736(97)03360-6]

12. Nemtsov A. Alcohol-related human losses in Russia in the 1980s and 1990s. Addiction 2002 Nov;97(11):1413-1425. [doi: 10.1046/j.1360-0443.2002.00262.x] [Medline: 12410782]

13. Wadhwa D. Men smoke 5 times more than women. World Bank Blogs. 2019 May 23. URL: https://blogs.worldbank.org/ opendata/ men-smoke-5-times-more-women\#: :text=Overall\%2C\%20smoking\%20is\%20most\%20prevalent,by\%20gender\%20is\%20more\%20extreme [accessed 2020-08-11]

14. Stockwell T, Andreasson S, Cherpitel C, Chikritzhs T, Dangardt F, Holder H, et al. The burden of alcohol on health care during COVID-19. Drug Alcohol Rev 2021 Jan;40(1):3-7 [FREE Full text] [doi: 10.1111/dar.13143] [Medline: 32835427] 
15. Saengow U, Assanangkornchai S, Casswell S. Alcohol: a probable risk factor of COVID-19 severity. Addiction 2021 Jan 12;116(1):204-205 [FREE Full text] [doi: 10.1111/add.15194] [Medline: 32688440]

16. Spagnolo PA, Montemitro C, Leggio L. New Challenges in Addiction Medicine: COVID-19 Infection in Patients With Alcohol and Substance Use Disorders-The Perfect Storm. Am J Psychiatry 2020 Sep 01;177(9):805-807. [doi: 10.1176/appi.ajp.2020.20040417] [Medline: 32660296]

17. Hamer M, Kivimäki M, Gale CR, Batty GD. Lifestyle risk factors, inflammatory mechanisms, and COVID-19 hospitalization: A community-based cohort study of 387,109 adults in UK. Brain Behav Immun 2020 Jul;87:184-187 [FREE Full text] [doi: 10.1016/j.bbi.2020.05.059] [Medline: 32454138]

18. Volkow N. Collision of the COVID-19 and Addiction Epidemics. Ann Intern Med 2020 Jul 07;173(1):61-62 [FREE Full text] [doi: 10.7326/M20-1212] [Medline: 32240293]

19. Hochstatter KR, Akhtar WZ, Dietz S, Pe-Romashko K, Gustafson DH, Shah DV, et al. Potential Influences of the COVID-19 Pandemic on Drug Use and HIV Care Among People Living with HIV and Substance Use Disorders: Experience from a Pilot mHealth Intervention. AIDS Behav 2020 Jul 23 [FREE Full text] [doi: 10.1007/s10461-020-02976-1] [Medline: $\underline{32705370]}$

20. Biddle N, Edwards B, Gray M, Sollis K. Alcohol consumption during the COVID-19 period: May 2020. ANU Centre for Social Research and Methods. 2020 May. URL: https://csrm.cass.anu.edu.au/sites/default/files/docs/2020/6/

Alcohol consumption during the COVID-19 period.pdf [accessed 2021-01-25]

21. Frishman WH, Del Vecchio A, Sanal S, Ismail A. Cardiovascular manifestations of substance abuse: part 2: alcohol, amphetamines, heroin, cannabis, and caffeine. Heart Dis 2003;5(4):253-271. [doi: 10.1097/01.hdx.0000080713.09303.a6] [Medline: 12877759]

22. Wu L, Zhu H, Ghitza UE. Multicomorbidity of chronic diseases and substance use disorders and their association with hospitalization: Results from electronic health records data. Drug Alcohol Depend 2018 Nov 01;192:316-323 [FREE Full text] [doi: 10.1016/j.drugalcdep.2018.08.013] [Medline: 30312893]

23. Degenhardt L, Charlson F, Ferrari A, Santomauro D, Erskine H, Mantilla-Herrara A, et al. The global burden of disease attributable to alcohol and drug use in 195 countries and territories, 1990-2016: a systematic analysis for the Global Burden of Disease Study 2016. Lancet Psychiatry 2018 Dec;5(12):987-1012. [doi: 10.1016/s2215-0366(18)30337-7]

24. COVID-19: Avoiding a 'second tragedy' for those with TB. Médecins Sans Frontières. 2020 Mar 23. URL: https://www. msf.org/covid-19-how-avoid-second-tragedy-those-tuberculosis [accessed 2020-08-09]

25. Fossat M. In remote Kyrgyzstan, COVID-19 puts a strain on the health system. Médecins Sans Frontières. 2020 Jul 22. URL: https://www.msf.org/kyrgyzstan-covid-19-strains-health-system [accessed 2020-08-09]

26. Sedik D. Europe and Central Asia - Regional overview of food insecurity. Food and Agriculture Organizations of the United Nations. 2017. URL: http://www.fao.org/3/a-i6877e.pdf [accessed 2021-01-25]

27. Europe and Central Asia Regional Overview of Food Security and Nutrition. Food and Agriculture Organization of the United Nations. 2019. URL: http://www.fao.org/3/ca7153en/CA7153EN.pdf [accessed 2021-01-25]

28. The State of Food Security and Nutrition in the World 2019. Food and Agriculture Organization of the United Nations. 2019. URL: https://docs.wfp.org/api/documents/WFP-0000106760/download/? ga=2.37517920.1134316896. 1611609114-2001096053.1611609114 [accessed 2021-01-25]

29. William SA. Economic and Social Impacts of COVID-19: Updates from the Listening to Tajikistan Survey. World Bank. 2020 Jul 13. URL: https://www.worldbank.org/en/news/factsheet/2020/07/13/ economic-and-social-impacts-of-covid-19-update-from-listening-to-tajikistan [accessed 2020-08-05]

30. Sapkota A. Water reuse, food production and public health: Adopting transdisciplinary, systems-based approaches to achieve water and food security in a changing climate. Environ Res 2019 Apr;171:576-580. [doi: 10.1016/j.envres.2018.11.003] [Medline: 30477872]

31. Micklin P. The Aral Sea disaster. Annu Rev Earth Planet Sci 2007 May;35(1):47-72. [doi: 10.1146/annurev.earth.35.031306.140120]

32. Burunciuc L. Improving water and sanitation in Central Asia requires determination and shared commitment. World Bank Blogs. 2019 Dec 24. URL: https://blogs.worldbank.org/europeandcentralasia/ improving-water-and-sanitation-central-asia-requires-determination-and-shared [accessed 2020-08-03]

33. Ataniyazova OA. COVID-19: High risk groups for COVID-19 and challenges for medical universities. Asian Pac J Envi \& Cancer 2020 Jul 17;3(S1):21-23. [doi: 10.31557/apjec.2020.3.s1.21-23]

34. Azam R, Idrees A. Economic growth, obesity and global burden of disease: an exploration. GCU Economic Journal 2019;:LII(1\&2):67-106.

35. Comas D, Calafell F, Mateu E, Pérez-Lezaun A, Bosch E, Martínez-Arias R, et al. Trading genes along the silk road: mtDNA sequences and the origin of central Asian populations. Am J Hum Genet 1998 Dec;63(6):1824-1838 [FREE Full text] [doi: 10.1086/302133] [Medline: $\underline{9837835}$ ]

36. Kuzmina E. In: Mair VH, editor. The Prehistory of the Silk Road. Philadelphia, PA: University of Pennsylvania Press; 2008.

37. Powles J, Fahimi S, Micha R, Khatibzadeh S, Shi P, Ezzati M, Global Burden of Diseases Nutrition and Chronic Diseases Expert Group (NutriCoDE). Global, regional and national sodium intakes in 1990 and 2010: a systematic analysis of $24 \mathrm{~h}$ 
urinary sodium excretion and dietary surveys worldwide. BMJ Open 2013 Dec 23;3(12):e003733 [FREE Full text] [doi: 10.1136/bmjopen-2013-003733] [Medline: 24366578]

38. Krause M, Gerchman F, Friedman R. Coronavirus infection (SARS-CoV-2) in obesity and diabetes comorbidities: is heat shock response determinant for the disease complications? Diabetol Metab Syndr 2020 Jul 16;12(1):63 [FREE Full text] [doi: 10.1186/s13098-020-00572-w] [Medline: 32690985]

39. Maukayeva S, Karimova S. Epidemiologic character of COVID-19 in Kazakhstan: A preliminary report. North Clin Istanb 2020;7(3):210-213 [FREE Full text] [doi: 10.14744/nci.2020.62443] [Medline: 32478290]

40. Global Economic Prospects: Europe and Central Asia. World Bank. 2020 Jun. URL: https://www.worldbank.org/en/region/ eca/brief/global-economic-prospects-europe-and-central-asia [accessed 2020-08-05]

41. Azamat AI, Izvorski IV, Rahardja S. Kazakhstan Economic Update: Navigating the Crisis. World Bank. 2020 Jul 22. URL: https://www.worldbank.org/en/country/kazakhstan/publication/economic-update-summer-2020 [accessed 2020-08-04]

42. Sumner A, Hoy C, Ortiz-Juarez E. Estimates of the Impact of COVID-19 on Global Poverty. UNU-WIDER. 2020 Apr. URL: https://www.wider.unu.edu/sites/default/files/Publications/Working-paper/PDF/wp2020-43.pdf [accessed 2021-01-25]

43. Valensisi G. COVID-19 and global poverty. Food and Agriculture Organization of the United Nations. 2020. URL: http:/ /www.fao.org/3/ca8824en/CA8824EN.pdf [accessed 2021-01-25]

44. Nogales R, Oldiges C, Dirksen J, Alkire S. Multidimensional Poverty and COVID-19 Risk Factors: A Rapid Overview of Interlinked Deprivations across 5.7 Billion People. Oxford Poverty \& Human Development Initiative. 2020. URL: https:/ lophi.org.uk/wp-content/uploads/B53 Covid-19 vs3-2 2020 online.pdf [accessed 2021-01-25]

45. Zar HJ, Dawa J, Fischer GB, Castro-Rodriguez JA. Challenges of COVID-19 in children in low- and middle-income countries. Paediatr Respir Rev 2020 Sep;35:70-74 [FREE Full text] [doi: 10.1016/j.prrv.2020.06.016] [Medline: 32654854]

46. Dutta P, Andrews C, de MA, Clay T, Chaudhary S. Economic Inclusion for the Poorest and COVID-19: Adaptation and Early Priorities for Medium- and Longer-Term Recovery. World Bank. 2020 Jun 18. URL: https://reliefweb.int/sites/ reliefweb.int/files/resources/77523 0.pdf [accessed 2021-01-25]

47. Russia: Health Workers Face Retaliation for Speaking Out. Human Rights Watch. 2020 Jun 15. URL: https://www.hrw.org/ news/2020/06/15/russia-health-workers-face-retaliation-speaking-out [accessed 2020-08-09]

48. Turkey: Probes Over Doctors' Covid-19 Comments. Human Rights Watch. 2020 Jun 10. URL: https://www.hrw.org/news/ 2020/06/10/turkey-probes-over-doctors-covid-19-comments [accessed 2020-08-09]

49. Turkmenistan Denies Apparent Covid-19 Outbreak. Human Rights Watch. 2020 Jun 07. URL: https://www.hrw.org/news/ 2020/06/27/turkmenistan-denies-apparent-covid-19-outbreak [accessed 2020-08-09]

50. Huseynov V. Azerbaijan hopes to minimize ramifications of coronavirus crisis?Analysis. The Jamestown Foundation. 2020 Apr 16. URL: https://jamestown.org/program/azerbaijan-hopes-to-minimize-ramifications-of-coronavirus-crisis/ [accessed 2021-01-25]

51. Samadov B. Azerbaijan-COVID-19 and a Divided Opposition. The COVID-19 Pandemic in the South Caucasus. 2020 May. URL: https://www.research-collection.ethz.ch/bitstream/handle/20.500.11850/415805/CAD115.

pdf? sequence $=2 \&$ is Allowed $=y$ [accessed 2021-01-25]

52. Armenia: Law Restricts Privacy Amid COVID-19 Fight. Human Rights Watch. 2020 Apr 03. URL: https://www.hrw.org/ news/2020/04/03/armenia-law-restricts-privacy-amid-covid-19-fight [accessed 2020-08-09]

53. Aitkhozhina D. Most Covid-19 restrictions lifted, but Moscow is not open for protest. Human Rights Watch. 2020 Jul 22. URL: https://www.hrw.org/news/2020/07/22/most-covid-19-restrictions-lifted-moscow-not-open-protest [accessed 2020-08-09]

54. IFPRI's COVID-19 policy response (CPR) portal: Identifying trends and implications for food systems. Nigeria Strategy Support Program. 2020 May 20. URL: http://nssp.ifpri.info/2020/05/20/ ifpris-covid-19-policy-response-cpr-portal-identifying-trends-and-implications-for-food-systems/ [accessed 2021-01-25]

55. Azerbaijan Monthly Economic Update. World Bank Group. 2020 Jul. URL: http://pubdocs.worldbank.org/en/ 443481594846767557/AZ-Monthly-Economic-Update-July-2020.pdf [accessed 2020-08-04]

56. Callaway E. Russia's fast-track coronavirus vaccine draws outrage over safety. Nature 2020 Aug;584(7821):334-335. [doi: 10.1038/d41586-020-02386-2] [Medline: 32782400 ]

57. Zimmer C. 'This Is All Beyond Stupid.' Experts Worry About Russia’s Rushed Vaccine. New York Times. 2020 Aug 11. URL: https://www.nytimes.com/2020/08/11/health/russia-covid-19-vaccine-safety.html [accessed 2020-08-14]

58. Neuman S. Putin Announces Approval Of A 2nd Unproven Coronavirus Vaccine. NPR. 2020 Oct 14. URL: https://www. npr.org/sections/coronavirus-live-updates/2020/10/14/923785152/

russias-putin-announces-approval-of-a-second-unproven-coronavirus-vaccine [accessed 2020-01-25]

59. Sherwin E. Russia's 'corona-holidays' leave small businesses in freefall. DW. 2020 Apr 03. URL: https://p.dw.com/p/3aQXo [accessed 2020-10-19]

60. WorldOMeter. Russia. Worldometer. URL: https://www.worldometers.info/coronavirus/country/russia/ [accessed 2020-10-19]

61. Sherwin E. Coronavirus: Russia tightens restrictions, but avoids lockdown. DW. 2020 Oct 16. URL: https://p.dw.com/p/

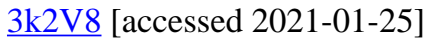

62. Coronavirus in Russia: The Latest News. The Moscow Times. URL: https://www.themoscowtimes.com/2020/10/19/ coronavirus-in-russia-the-latest-news-oct-19-a69117 [accessed 2020-10-19] 
63. Teutsch SM. Considerations in Planning a Surveillance System. In: Principles \& Practice of Public Health Surveillance. Oxford, UK: Oxford Scholarship Online; 2010:18-28.

64. Teutsch S, Churchill R. Principles and Practice of Public Health Surveillance. Oxford, UK: Oxford University Press; 2000.

65. Teutsch SM, Thacker SB. Planning a public health surveillance system. Epidemiological bulletin 1995;16(1):1.

66. Thacker S, Berkelman R. Public health surveillance in the United States. Epidemiol Rev 1988;10(1):164-190. [doi: 10.1093/oxfordjournals.epirev.a036021] [Medline: 3066626]

67. Thacker S, Choi K, Brachman P. The surveillance of infectious diseases. JAMA 1983 Mar 04;249(9):1181-1185. [Medline: 6823080]

68. Thacker S, Stroup D. Future directions for comprehensive public health surveillance and health information systems in the United States. Am J Epidemiol 1994 Sep 01;140(5):383-397. [doi: 10.1093/oxfordjournals.aje.a117261] [Medline: 8067331$]$

69. Thacker S, Stroup D. Public Health Surveillance and Health Services Research. In: Armenian HK, Shapiro S, editors. Epidemiology and Health Services. New York, NY: Oxford University Press; 1998:61-82.

70. Thacker SB, Stroup DF, Parrish RG, Anderson HA. Surveillance in environmental public health: issues, systems, and sources. Am J Public Health 1996 May;86(5):633-638. [doi: 10.2105/ajph.86.5.633] [Medline: $\underline{\text { 8629712] }}$

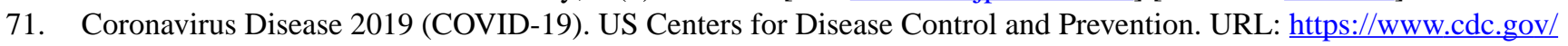
coronavirus/2019-ncov/index.html [accessed 2021-01-25]

72. Global Surveillance for human infection with coronavirus disease (COVID-19). World Health Organization. URL: https:/ lapps.who.int/iris/handle/10665/330857 [accessed 2021-01-25]

73. EU level surveillance of COVID-19. European Center for Disease Prevention and Control. URL: https://www.ecdc.europa.eu/ en/covid-19/surveillance [accessed 2021-01-25]

74. COVID-19 Surveillance Dashboard. African Union. URL: https://au.int/en/covid19 [accessed 2021-01-25]

75. Hannah RE, Diana B, Edouard M, Joe H, Bobbie M, Charlie G, et al. Coronavirus Pandemic (COVID-19) - the data. Our World in Data. URL: https://ourworldindata.org/coronavirus-data [accessed 2020-08-14]

76. COVID-19 Situation Dashboard. European Centre for Disease Prevention and Control. URL: https://qap.ecdc.europa.eu/ public/extensions/COVID-19/COVID-19.html [accessed 2021-01-25]

77. Coronavirus Resource Center. Johns Hopkins University of Medicine. URL: https://coronavirus.jhu.edu/ [accessed 2021-01-25]

78. Coronavirus Outbreak. Bloomberg. URL: https://www.bloomberg.com/coronavirus [accessed 2021-01-25]

79. US Coronavirus Cases and Deaths: Track COVID-19 data daily by state and county. USA Facts. URL: https://usafacts.org/ visualizations/coronavirus-covid-19-spread-map/ [accessed 2021-01-25]

80. Oehmke J, Moss C, Singh L, Oehmke T, Post L. Dynamic Panel Surveillance of COVID-19 Transmission in the United States to Inform Health Policy: Observational Statistical Study. J Med Internet Res 2020 Oct 05;22(10):e21955 [FREE Full text] [doi: 10.2196/21955] [Medline: 32924962]

81. Oehmke J, Oehmke T, Singh L, Post L. Dynamic Panel Estimate-Based Health Surveillance of SARS-CoV-2 Infection Rates to Inform Public Health Policy: Model Development and Validation. J Med Internet Res 2020 Sep 22;22(9):e20924 [FREE Full text] [doi: 10.2196/20924] [Medline: 32915762]

82. Abdurasulov A. Coronavirus: Why has Turkmenistan reported no cases? BBC. 2020 Apr 07. URL: https://www.bbc.com/ news/world-asia-52186521 [accessed 2020-08-14]

83. SARS-CoV-2 Test Tracker. Foundation for Innovative New Diagnostics. URL: https://www.finddx.org/covid-19/test-tracker/ [accessed 2020-10-14]

84. FINDCov19TrackerData. GitHub. URL: https://github.com/dsbbfinddx/FINDCov19TrackerData [accessed 2021-01-25]

85. Hansen LP. Large Sample Properties of Generalized Method of Moments Estimators. Econometrica 1982 Jul;50(4):1029. [doi: 10.2307/1912775]

86. Post L. Global SARS-CoV-2 Surveillance Policy, Persistence, and Transmission - Central Asia. Tableau Public. 2020 Oct 22. URL: https://public.tableau.com/profile/lori.post\#!/vizhome/ GlobalSARS-CoV-2SurveillancePolicyPersistenceandTransmission-CentralAsia/Story [accessed 2021-01-26]

87. Iacopini I, Petri G, Barrat A, Latora V. Simplicial models of social contagion. Nat Commun 2019 Jun 06;10(1):2485 [FREE Full text] [doi: 10.1038/s41467-019-10431-6] [Medline: 31171784]

88. Stock JH. Data gaps and the policy response to the novel coronavirus. National Bureau of Economic Research. 2020. URL: https://www.nber.org/system/files/working papers/w26902/w26902.pdf [accessed 2021-01-25]

89. Desjardins M, Hohl A, Delmelle E. Rapid surveillance of COVID-19 in the United States using a prospective space-time scan statistic: Detecting and evaluating emerging clusters. Appl Geogr 2020 May;118:102202 [FREE Full text] [doi: 10.1016/j.apgeog.2020.102202] [Medline: 32287518]

90. Shi F, Wang J, Shi J, Wu Z, Wang Q, Tang Z, et al. Review of Artificial Intelligence Techniques in Imaging Data Acquisition, Segmentation, and Diagnosis for COVID-19. IEEE Rev Biomed Eng 2021;14:4-15. [doi: 10.1109/rbme.2020.2987975]

91. Naudé W. Artificial Intelligence against COVID-19: An early review. IZA Institute of Labor Economics. 2020 Apr. URL: http://ftp.iza.org/dp13110.pdf [accessed 2021-01-25]

92. Tang Z, Zhao W, Xie X, Zhong Z, Shi F, Liu J, et al. Severity assessment of coronavirus disease 2019 (COVID-19) using quantitative features from chest CT images. ArXiv. Preprint posted online on March 26, 2020 [FREE Full text] 
93. Interim clinical guidance for management of patients with confirmed coronavirus disease (COVID-19). Centers for Disease Control and Prevention. 2020 Jun 30. URL: https://stacks.cdc.gov/view/cdc/89980 [accessed 2021-01-25]

94. Lipsitch M, Cohen T, Cooper B, Robins JM, Ma S, James L, et al. Transmission dynamics and control of severe acute respiratory syndrome. Science 2003 Jun 20;300(5627):1966-1970 [FREE Full text] [doi: 10.1126/science.1086616] [Medline: 12766207]

95. Lipsitch M, Swerdlow DL, Finelli L. Defining the epidemiology of COVID-19 — studies needed. N Engl J Med 2020 Mar 26;382(13):1194-1196. [doi: 10.1056/nejmp2002125]

96. Zhao S, Gao D, Zhuang Z, Chong MKC, Cai Y, Ran J, et al. Estimating the serial interval of the novel coronavirus disease (COVID-19): A statistical analysis using the public data in Hong Kong from January 16 to February 15, 2020. Research Square. Preprint posted online on May 27, 2020 [FREE Full text] [doi: 10.21203/rs.3.rs-18805/v3]

97. Gatto M, Bertuzzo E, Mari L, Miccoli S, Carraro L, Casagrandi R, et al. Spread and dynamics of the COVID-19 epidemic in Italy: Effects of emergency containment measures. Proc Natl Acad Sci USA 2020 May 12;117(19):10484-10491 [FREE Full text] [doi: 10.1073/pnas.2004978117] [Medline: 32327608]

98. You C, Deng Y, Hu W, Sun J, Lin Q, Zhou F, et al. Estimation of the time-varying reproduction number of COVID-19 outbreak in China. Int J Hyg Environ Health 2020 Jul;228:113555 [FREE Full text] [doi: 10.1016/j.ijheh.2020.113555] [Medline: 32460229]

99. Sanche S, Lin YT, Xu C, Romero-Severson E, Hengartner N, Ke R. High contagiousness and rapid spread of severe acute respiratory syndrome coronavirus 2. Emerg Infect Dis 2020 Jul;26(7):1470-1477 [FREE Full text] [doi: 10.3201/eid2607.200282] [Medline: 32255761]

100. Giordano G, Blanchini F, Bruno R, Colaneri P, Di Filippo A, Di Matteo A, et al. Modelling the COVID-19 epidemic and implementation of population-wide interventions in Italy. Nat Med 2020 Jun 22;26(6):855-860 [FREE Full text] [doi: 10.1038/s41591-020-0883-7] [Medline: 32322102]

101. Nishiura H, Linton N, Akhmetzhanov A. Serial interval of novel coronavirus (COVID-19) infections. Int J Infect Dis 2020 Apr;93:284-286 [FREE Full text] [doi: 10.1016/j.ijid.2020.02.060] [Medline: $\underline{\text { 32145466] }}$

102. Lai C, Shih T, Ko W, Tang H, Hsueh P. Severe acute respiratory syndrome coronavirus 2 (SARS-CoV-2) and coronavirus disease-2019 (COVID-19): The epidemic and the challenges. Int J Antimicrob Agents 2020 Mar;55(3):105924 [FREE Full text] [doi: 10.1016/j.ijantimicag.2020.105924] [Medline: $\underline{\text { 32081636] }}$

103. Martcheva M, Castillo-Chavez C. Diseases with chronic stage in a population with varying size. Mathematical Biosciences 2003 Mar;182(1):1-25. [doi: 10.1016/s0025-5564(02)00184-0]

104. Chen L. Persistent spatial patterns of interacting contagions. Phys. Rev. E 2019 Feb 14;99(2):022308. [doi: 10.1103/physreve.99.022308]

105. Kwuimy CAK, Nazari F, Jiao X, Rohani P, Nataraj C. Nonlinear dynamic analysis of an epidemiological model for COVID-19 including public behavior and government action. Nonlinear Dyn 2020 Jul 16;101(3):1-15 [FREE Full text] [doi: 10.1007/s11071-020-05815-z] [Medline: 32836814]

106. Li X, Yang J, Martcheva M. Age Structured Epidemic Modeling. New York, NY: Springer; 2019.

\section{Abbreviations}

FIND: Foundation for Innovative New Diagnostics

$\mathbf{R}_{\mathbf{0}}$ : basic reproduction number

USSR: Union of Soviet Socialist Republics

Edited by G Eysenbach; submitted 16.11.20; peer-reviewed by A Seidmann; comments to author 07.12.20; revised version received
09.12.20; accepted 20.01.21; published 03.02.21
Please cite as:
Post LA, Benishay ET, Moss CB, Murphy RL, Achenbach CJ, Ison MG, Resnick D, Singh LN, White J, Chaudhury AS, Boctor MJ,
Welch SB, Oehmke JF
Surveillance Metrics of SARS-CoV-2 Transmission in Central Asia: Longitudinal Trend Analysis
J Med Internet Res $2021 ; 23(2): e 25799$
URL: $\underline{\text { https://www.jmir.org/2021/2/e25799 }}$
doi: $\underline{10.2196 / 25799}$
PMID: $\underline{33475513}$

CLori Ann Post, Elana T Benishay, Charles B Moss, Robert Leo Murphy, Chad J Achenbach, Michael G Ison, Danielle Resnick, Lauren Nadya Singh, Janine White, Azraa S Chaudhury, Michael J Boctor, Sarah B Welch, James Francis Oehmke. Originally published in the Journal of Medical Internet Research (http://www.jmir.org), 03.02.2021. This is an open-access article distributed 
under the terms of the Creative Commons Attribution License (https://creativecommons.org/licenses/by/4.0/), which permits unrestricted use, distribution, and reproduction in any medium, provided the original work, first published in the Journal of Medical Internet Research, is properly cited. The complete bibliographic information, a link to the original publication on http://www.jmir.org/, as well as this copyright and license information must be included. 